Article

\title{
Do Employees Matter in the Relationship between Corporate Social Responsibility and Financial Performance?
}

\author{
Jae Mee Yoo, Woojae Choi * and Mi Lim Chon \\ School of Business Administration, Cheongju University, Cheongju 28503, Korea; yoojm@cju.ac.kr (J.M.Y.); \\ milim@cju.ac.kr (M.L.C.) \\ * Correspondence: choiwj@cju.ac.kr
}

Received: 2 October 2019; Accepted: 4 November 2019; Published: 7 November 2019

check for updates

\begin{abstract}
This study investigated the mechanism behind the impact of corporate social responsibility (CSR) on firms' financial performance while focusing on internal stakeholders. Although many studies have examined the effects of CSR few has empirically investigated the underlying process of the mechanism. In addition, previous research has rarely regarded employees as a link between CSR and firms' outcomes, despite employees implementing CSR policies. This study explored the pathway of the CSR-employees-firm's performance. Employee commitment was used to explain the relationship between CSR and performance, since it is an important employee-associated micro-level outcome of CSR. The results showed that CSR indirectly influenced a firm's accounting profitability through enhanced employee commitment, as well as directly affected firm's profitability. CSR increases employee commitment, which in turn leads to improvements in a firm's accounting returns. The paper suggests that employees should be considered as an important agent for the effects of CSR initiatives.
\end{abstract}

Keywords: CSR; employee commitment; financial performance

\section{Introduction}

Corporate social responsibility (CSR) has received increasing attention in both business and academia. An international survey of corporate social reporting conducted by KPMG in 2017 found that $93 \%$ of the world's 250 largest companies had published reports on their CSR activities (https://home.kpmg.com/content/dam/kpmg/campaigns/csr/pdf/CSR_Reporting_2017.pdf. accessed on 2 December 2018). The survey also showed that $78 \%$ of the companies include CSR information in their annual financial reports, indicating that they believed CSR data were relevant for their investors. The number of companies represents how CSR has become a prevalent business practice. As CSR is becoming a mandatory trend in organizational operation due to the increasing expectations of society for companies, many companies have been devoting resources to CSR initiatives as a means of maximizing long-term value [1]. Public demands, as well as intense competition and market uncertainty, have also made CSR a vital strategy that firms could employ to ensure long-term sustainability beyond their ethical obligations [2].

Along this vein, it is necessary to explore whether CSR produces outcomes beyond moral obligations for a company. In an instrumental approach where corporate social activities are seen as a means to achieve economic profits, CSR practices have been analyzed as being associated with a firm's financial performance. Many studies have found a positive association between CSR and a firm's financial performance. However, it is also evident that CSR cannot result in an improved performance for all firms all the time [3,4]. Therefore, further investigation into the underlying mechanisms that drive favorable returns of firms' investments in CSR is required [5]. 
CSR researchers with an instrumental perspective have adopted stakeholder theory to explain the link between CSR and a firm's performance. According to stakeholder theory, a company establishes a reciprocal relationship with various stakeholders, whereby the company and its stakeholders affect and are affected by each other through the firm's practices [6]. They assert that a firm's CSR practices can build a favorable relationship with their stakeholders and, if the relationship is positive and stable, this leads, in turn, to enhanced firm performance. Little research, however, has empirically investigated how the established relationship with stakeholders is connected to firm's performance. In addition, most studies adopting stakeholder perspective have focused on external stakeholders (e.g., consumers) because consumers directly affect a firm's financial performance through their purchasing behavior [7]. As a result, less attention has been paid to internal stakeholders $[5,7,8]$.

This study investigates the mechanism of the impact of CSR on a firm's accounting-based performance in Korea. This has two implications: seeing the impact of CSR on the fundamental value of a company rather than market expectations, and exploring CSR effects in countries with less research than the developed countries (e.g., US and Europe). To explore the mechanism by which CSR works, employees as internal stakeholders have been viewed as both recipients of and contributors to CSR initiatives [9]. In particular, this study focuses on employee commitment. Employee commitment has been shown to play a critical role in the relationship between a firm's systems and practices, and its performance [10]. Drawing on social identity theory (SIT), this study delineates the mechanism of how CSR strengthens the employee-organization relationship, and subsequently fosters a firm's financial performance. Understanding how employees create value in the relationship between CSR and firm's performance provides a more integrated picture of CSR in strategic management.

To verify the mechanism of CSR effect, this study uses multi-sourced data. CSR used the Korea Economic Justice Institute (KEJI) index which contains third party ratings and is similar to the Kinder, Lydenberg, Domini Research and Analytics(KLD). Corporate financial performance used return on assets (ROA) and return on equity (ROE). Employee commitment used an external secondary data collected by the Korea Research Institute of Vocational Education and Training (KRIVET). Multi-sourced data might overcome the limitation of the existing findings that relied on employee's perception of CSR initiatives and outcomes.

\section{Theoretical Background and Hypothesis}

\subsection{CSR and Financial Performance}

The definition of CSR has changed over time as a growing body of literature has developed from various disciplinary fields. CSR, at its roots, refers to the obligations of a company toward society [11,12]. Carroll [12] divided these responsibilities into four specific categories: economic, legal, ethical, and philanthropic. Companies have economic responsibilities to produce goods and services that society wants, and to provide them at a profit. Stakeholders expect companies to fulfill their economic benefits within a legally accepted framework. Stakeholders also anticipate that companies will behave ethically, beyond their legal requirements. Philanthropic responsibilities, at the highest level, exceed simple economic responsibilities and call for companies to build a better society by donating services to the community and engaging in environmental protection. Schwartz and Carroll [13] later regrouped these responsibilities into three categories: economic, legal, and ethical. CSR initiatives have rapidly become part of the agenda for the sustainable growth of companies. Early research tended to measure CSR as a single dimension, such as donations and environmental protection, which made it hard to appreciate the comprehensive nature of CSR. To overcome this limitation, most recent studies have measured CSR with several dimensions.

Most CSR research to date has focused on the relationship between CSR and a firm's performance. The proliferation of this research stream reflects the prevailing belief that CSR is not only an ethical imperative, but also an economic one, while serving as a strategic instrument to achieve economic 
objectives in the marketplace [2]. Corporate social activities are seen as a means to obtain economic profits in terms of the instrumental perspective [14].

Many instrumental studies have found a positive relationship between CSR and a firm's performance. For example, Waddock and Graves [15] found that corporate social performance improved a firm's financial performance. Luo and Bhattacharya [16] also found that CSR led to increased market value. Chon and Yoo [17] investigated the same issue by using data from a CSR index and the financial performance, and found that CSR activities positively influenced a firm's ROA and Tobin's Q in the Korean market. Studies trying to empirically demonstrate the existence of a direct link between CSR and a firm's economic performance have so far produced mixed results [18], whereas meta-analyses have found a weak positive link.

Margolis and Walsh [19] reviewed 109 instrumental studies and found that 54 of them showed a positive relationship between CSR and a firm's performance. In the review, 28 studies reported a non-significant relationship, 20 reported mixed findings, and seven studies identified negative relationships. Orlitzky et al. [20] also revealed the positive impact of CSR on performance through a meta-analysis of relevant studies. A more recent review identified the impact of sustainability practices on corporate financial performance through a meta-analysis of 132 studies [3]. It found that $78 \%$ of publications had demonstrated a positive relationship between corporate sustainability and financial performance. Among the 132 studies, $7 \%$ found a no-impact relationship and $6 \%$ found a negative impact. The study regarded CSR in a narrow way, focusing on the social dimension of total sustainability. The positive impact of CSR has prevailed in most findings, and the mixed effect can be attributed to a variety of shortcomings, including sampling and measurement errors, along with conceptual, operational, and methodological differences in the definitions of CSR and financial performance [3,5]. This study expects to reduce the controversial results due to measurement by using objective and structured data related to CSR, and accounting profitability as a firm's financial performance.

Research from an instrumental perspective has explained the positive link between CSR and a firm's performance by employing stakeholder theory [21]. Stakeholder theory views companies in the context of their environment by considering their relationship with many constituent groups and individuals, such as owners, management, shareholders, employees, suppliers, customers, and the local community. These stakeholders affect and are affected by a firm's policies and practices [6]. The concept focuses on the two-way relationship between firms and stakeholders, as well as the bidirectional interaction of stakeholders with each other [22].

Research using stakeholder theory to assess the impact of CSR suggests that a firm's CSR can influence stakeholders, thus stakeholders can also affect a firm's outcomes. CSR improves the quality of the relationship with the stakeholders of the firm, as the organization undertakes diverse CSR initiatives to meet the expectations of their stakeholders. An enhanced relationship between an organization and its stakeholders obtained through CSR activities leads to positive returns of investment in CSR [22-24]. Fulfilling the divergent requirements of stakeholders contributes to better financial performance. Therefore, our hypothesis is as follows:

Hypothesis 1. CSR will be positively related to financial performance.

\subsection{Employee Commitment as a Mediator}

Employees are stakeholders who are vital to the survival and success of the corporation [25]. Employees act as agents for social change when they ask corporations to embrace socially responsible behaviors [26] because they, as a group of various stakeholders, perceive, evaluate, judge, and react to the organization's practices and policies [27]. Although many empirical studies have examined employee attitudes and behaviors as outcomes of CSR systems or activities, few studies have investigated the influence of employees on financial performance in the CSR literature.

In order to investigate the mechanism of the underlying influence of CSR on a firm's financial performance, employee commitment was selected as a critical measure of employee attitudes. Employee 
commitment has been regarded as a predictor of corporate performance and as a consequence of corporate social responsibility behavior in the literature (e.g., [28-33]). Employee commitment refers to the degree an employee's identification with and engagement in a particular organization [34].

The role of employee commitment in the CSR literature has been mainly explained by SIT [35]. Early studies of SIT originating from Tajfel and Turner [36] argued that people utilize different categorization schema to define themselves and others in the social environment. The self-concept in SIT is comprised of both personal identity, including idiosyncratic characteristics, and social identity, encompassing differential classification. Ashforth and Mael [37] later applied SIT to organizational socialization and proposed that the distinctiveness of the organization's values and practices served to separate it from others and to provide a unique identity. Furthermore, the prestige of the organization increased its employees' self-esteem and was related to salience, with respect to other organizations. Research has shown that employees feel more attached to and identify themselves with their organization when it actively conducts socially responsible behaviors and exhibits concerns toward employees, as well as the community [38]. An organization's engagement in social issues and environmental protection creates a positive image for it, which affects employee commitment [39].

CSR improves the image of an organization, which enhances employee pride and the willingness of employees to be associated with an organization, as it is perceived as reputable [29]. Employees' strong associations with their organization induce positive employee attitudes and behavior. In the CSR literature, research has shown a positive and significant impact of CSR on employee commitment. Turker [33] examined the impacts of socially responsible behaviors toward four types of stakeholders on employee commitment with a sample set of Turkish professionals, and found that CSR initiatives focused on social and non-social stakeholders, employees, and customers positively affected employee commitment, but CSR of the government did not. Similarly, Brammer et al. [29] found that external CSR encompassing philanthropy and community contributions had a positive impact on the commitment of employees who worked at a retail banking services firm in the United Kingdom. Peterson [32] also found that perceptions of corporate citizenship were positively related to employee commitment.

Although studies have presented theoretical and empirical evidence for the impacts of CSR on employee commitment, there has been a lack of understanding of the mechanism by which CSR influences a firm's performance through its employees. In this vein, Gond and Moon [10] argued that distinct and parallel research streams have resulted in incomplete understandings of CSR; that is, macro-level research has seen organizations as the main unit of analysis, focusing on the financial impact of CSR, while micro-level research has considered individuals as the unit of analysis and has overlooked the effects of employees on financial outcomes. These two different perspectives have resulted in a gap between macro-level and micro-level analyses in the CSR literature [26]. In response to the call for convergent perspectives, De Roeck and Maon [31] suggested that the path-dependence framework was descriptive of how CSR influences employees' attitudes and behaviors, leading to changes in firm performance. In this framework, employee commitment is recognized as a major consequence of a corporation's ethical behavior, and one of the major determinants of a corporation's performance.

Knowledge from the literature on strategic human resource management (SHRM) has also increased our understanding of the link between CSR, employees, and firm performance. The SHRM literature (e.g., [40]) suggests that human resource management (HRM) systems operate upward at the financial and market levels through employees as the lower level. Becker, Huselid, Pinckus, and Spratt [41] argued that HRM practices affect employee attitudes and behaviors, which in turn influence the financial performance. CSR can be viewed as one of the substantial systems that influences organizational performance through the transformation of employee attitudes and behaviors. Chun et al. [30] explored how CSR affected firm performance through employee attitudes and behaviors. The study revealed that CSR indirectly influences firm performance via collective employee commitment and organizational citizenship behavior. In addition, it suggested that organizational policies, practices, and activities influence a firm's performance through enhanced employee commitment. 
Based on the CSR-employee-firm performance framework [31] and empirical evidence, this study suggests that CSR affects firm performance through its impact on employee commitment. Therefore, our hypothesis is as follows:

Hypothesis 2. Employee commitment will mediate the relationship between CSR and financial performance.

\section{Methods}

\subsection{Data and Measures}

To examine our hypotheses, we employed three databases in Korea: the KEJI database, Human Capital Corporate Panel (HCCP) database, and KisValue database. The first database is the KEJI index comparable to the Kinder, Lydenberg, Domini Research and Analytics (KDL) index in the US that has been used in many CSR studies (e.g., $[15,18,20,42])$ to investigate CSR activities. The KEJI annually evaluates CSR performances of approximately 400 firms in Korea. The KEJI assesses multidimensional corporate social performances and rates each company according to six categories of CSR: soundness, fairness, contribution to society, consumer protection, environmental protection, and employee satisfaction. This multidimensional index comprehensively reflects the various areas of CSR activities [21,43-45]). Furthermore, the KEJI index has been widely used in academia in Korea (e.g., $[17,46,47])$ so we adopted the KEJI index as a proxy of CSR activities.

The second database is HCCP which has been biannually collected by the Korea Research Institute of Vocational Education and Training (KRIVET) since 2005. The measure of employee commitment was drawn from HCCP data. HCCP comprises three items adapted from Meyer and Allen [48]. The items are "I feel as if this organization's problems are my own", "This is a worthwhile organization to work for", and "I feel a strong sense of belonging to this organization". The items were rated on a five-point Likert-scale ranging from "strongly disagree" to "strongly agree". The aggregation of individuals' responses was converted to the firm level. To justify the aggregation, interclass correlation coefficient (ICC) (1) and ICC (2) were calculated to ensure whether the aggregation was justified and reliable [49]. The values of 0.14 for ICC (1) and 0.87 for ICC (2) indicated that the aggregated measure of employee commitment was appropriate.

The third database is KisValue. Firm's financial performance was measured with two accounting-based ratios: return on assets (ROA) calculated with earnings before interest and taxes (EBIT) divided by total assets and ROE calculated with EBIT divided by total equity. ROA and ROE have been extensively used as proxies for firm's financial performance in terms of profitability (e.g., $[15,21])$. CSR performance is more highly correlated with accounting-based measures and less correlated with market-based measures [20].

In addition to the research variables, firm size (size), leverage (Lev), advertising expense (Ads), industry, and year were operationalized as control variables. Firm size was measured as the natural logarithm of total assets. Large firms have economies of scale and more external shareholders and are thus more likely to promote profitability. Leverage was computed as the ratio of total debt divided by total assets and was included to measure the level of financial pressure. Advertising makes consumers aware of product differentiation and entry barriers that might serve to enhance firm profitability [45]. The advertising expense was computed as the ratio of advertising expense divided by total assets. The sample was comprised of firms in various industries. The financial performance of firms may be influenced by industry characteristics, such as the competitive intensity and industry growth rate, as well as market events occurring each year. Therefore, the industry dummy and year dummy were also included, which were classified into nine and three categories, respectively.

\subsection{Empirical Models}

When we investigate both direct (H1) and indirect (H2) effects of CSR on firm's financial performance, the potential endogeneity of CSR variable arise from two reasons. First, CSR and financial 
performance could have no direct effect on each other but they might be significantly correlated through the third variable. Second, there could be a reverse causality from financial performance to CSR. In other words, CSR may lead to better financial performance, but better financial performance may result in increased CSR performance. It was difficult to find the third variable to solve the endogeneity problem because variables such as industry and firm age used in previous research were not appropriate for this study. One way to ensure the problem of reverse causality is to differentiate the measurement points of research variables. To do so, we selected data from time $t$ for CSR and employee commitment and time $t+1$ for financial performance. The interval between time $t$ and time $t+1$ was one year. The dependent variable was measured by the lagged value of ROA and ROE in these regression models to solve endogeneity problem.

Model 1 represented direct effect of CSR on financial performance. In model 2, we tested indirect effect of employee commitment between CSR and financial performance. To investigate the direct effect of CSR on a firm's financial performance (H1), model 1 included the ROA and ROE from time $t+1$ as dependent variables and CSR from time $t$ as an independent variable. Model 2 was analyzed according to method of Baron and Kenny [50] which tested mediation hypotheses with three regression analyses. First, the independent variable (CSR) must predict the dependent variable (financial performance). Second, the independent variable must predict the mediator (employee commitment). Finally, both independent variable and/or mediator must predict dependent variable. The study estimated Model 1 as the first regression. Model 2 as the second regression included CSR as independent variable and employee commitment (EC) as dependent variable. Model 3 included both CSR and EC from time $t$ as independent variables and financial performance from $t+1$ as the dependent variable.

The following conditions must be met to support mediation effect. CSR is shown to significantly influence the dependent variable (financial performance) in the first regression. Additionally, CSR is shown to significantly influence the mediator (EC) in the second regression. If the coefficients of employee commitment are significant in Model 3 where CSR and EC are entered as predictors, the results present the indirect effect which CSR has on influencing financial performance by increasing employee commitment. Both direct and indirect effects are estimated as below:

$$
\begin{gathered}
\mathrm{FPi}, \mathrm{t}+1=\alpha 0+\alpha 1 \text { CSRt }+\alpha 2 \text { Sizet }+\alpha 3 \text { Levt }+\alpha 4 \text { Adst }+\alpha 5 \text { Industry }+\alpha 6 \text { Year }+\varepsilon \ldots \\
\mathrm{ECt}=\alpha 0+\alpha 1 \text { CSRt }+\alpha 2 \text { Sizet }+\alpha 3 \text { Levt }+\alpha 4 \text { Adst }+\alpha 5 \text { Industry }+\alpha 6 \text { Year }+\varepsilon \ldots \\
\mathrm{FPi}, \mathrm{t}+1=\alpha 0+\alpha 1 \text { CSRt }+\alpha 2 \text { ECt }+\alpha 3 \text { Sizet }+\alpha 4 \text { Lev } \mathrm{t}+\alpha 5 \text { Ads } \mathrm{t}+\alpha 6 \text { Industry }+\alpha 7 \text { Year }+\varepsilon \ldots
\end{gathered}
$$

$\mathrm{FP}=\mathrm{ROA}(\mathrm{EBIT} /$ Total assets) and ROE (EBIT/Total equity); CSR = total scores of CSR, measured in six social categories of KEJI ratings data, including soundness, fairness, contribution to society, consumer protection, environmental protection, and employee satisfaction; EC = average commitment score of the respondent of a firm; Size $=$ natural logarithm of total assets; Lev $=$ total debt/total assets; Ads $=(\text { advertising expense/total assets })^{*} 100 ;$ Industry $=$ industry dummy variables; and Year $=$ year dummy variables.

\subsection{Sample Selection}

KEJI index database for CSR and KisValue database for firm's financial performance have been annually disclosed. HCCP database for employee commitment has been biannually collected by KRIVET. To match these three databases and minimize the potential problem of endogeneity, this study used HCCP data for three periods of time of 2011, 2013 and 2015. Then, the measure of employee commitment was matched with CSR index for that year. Finally, firm's financial performances of time $t$ + 1 (i.e., 2012, 2014, and 2016) were combined with both CSR index and employee commitment. The firms included in this study had the following selection criteria: (1) firms in a non-financial industry; (2) fiscal year ending on 31 December; (3) not impaired capital and (4) unqualified audit opinion. 
After matching three databases we eliminated observations with missing data. Total number of firms was 179 including 72 (year of 2011), 60 (year of 2013), and 47 (year of 2015). Total number of employees was 5422 comprising 1893(year of 2011), 1838(year of 2013), and 1711(year of 2015). The average number of employees per firm was 27.1 (year of 2011), 30.4 (year of 2013), and 35.5 (year of 2015). Table 1 shows the structure of sample.

Table 1. Structure of sample.

\begin{tabular}{ccccc}
\hline Year & CSR(t) & EC(t) & FP (t+ 1) & Sample \\
\cline { 2 - 5 } & $\begin{array}{c}\text { KEJI } \\
\text { Total observation }\end{array}$ & $\begin{array}{c}\text { HCCP } \\
\text { Total observation } \\
\text { (firm/employee) }\end{array}$ & KisValue & $\begin{array}{c}\text { KEJI + HCCP+ } \\
\text { KisValue } \\
\text { (firm/employee) }\end{array}$ \\
\hline 2011 & 408 & $456 / 10,064$ & - non-financial industry & $72 / 1893$ \\
2013 & 403 & $422 / 10,043$ & - fiscal year ended on 31Dec. & $60 / 1838$ \\
2015 & 387 & $411 / 10,069$ & - not impaired capital & - unqualified audit opinion. \\
\hline Total & 1198 & $1289 / 30,176$ & & $47 / 1711$ \\
\hline
\end{tabular}

Table 2 presents the sample distribution by industry. The most represented industry was chemicals and allied products (18.99\%), followed by electronic and other electric equipment (15.07\%), and primary and fabricated metal (13.41\%).

Table 2. Distribution of firms by industry.

\begin{tabular}{ccc}
\hline Industry & Number of Obs. & Percent (\%) \\
\hline Chemicals and Allied Products & 34 & 18.99 \\
Electronic and Other Electric Equipment & 26 & 14.53 \\
Food and Beverage & 17 & 9.50 \\
Instruments and Related Products & 15 & 8.38 \\
Pharmaceuticals & 10 & 5.59 \\
Primary and Fabricated Metal & 24 & 13.41 \\
Transportation Equipment & 16 & 9.84 \\
Other Manufacturing & 28 & 15.64 \\
Services & 9 & 5.03 \\
\hline Total & 179 & 100.00 \\
\hline
\end{tabular}

\section{Results}

Table 3 provides descriptive statistics for the variables used in this study, including the mean, median, standard deviation, minimum, maximum, and 25th and 75th percentiles. The mean and median of the ROA were 5.40 and 4.81 , respectively. The mean and median of the ROE were 8.69 and 7.50, respectively. CSR had a mean of 63.09 and a median of 62.98 , with a standard deviation of 2.58. Employee commitment had a mean of 3.47 and a median of 3.43. For the control variables, the means of firm size (size) and leverage (Lev) were 26.54 and 79.10, respectively. On average, the firms' advertising expense (Ads) of the sample was approximately $0.794 \%$ of their total assets.

Table 4 shows the Pearson's correlation coefficients for the variables. The financial performance measures (ROA and ROE) were significantly and positively correlated with CSR and EC under the significant level of $1 \%$. Furthermore, CSR was significantly and positively correlated with EC under the $1 \%$ significant level. In contrast, Lev was negatively correlated with ROA but not correlated with ROE. These results suggest that firms with better CSR are more likely to have a better financial performance. 
Table 3. Descriptive statistics.

\begin{tabular}{|c|c|c|c|c|c|c|c|c|}
\hline \multirow{2}{*}{ Variable } & \multirow{2}{*}{$\mathbf{N}$} & \multirow{2}{*}{ Mean } & \multirow{2}{*}{ Median } & \multirow{2}{*}{ Std.D. } & \multirow{2}{*}{ Min } & \multirow{2}{*}{ Max } & \multicolumn{2}{|c|}{ Percentiles } \\
\hline & & & & & & & 25th & 75th \\
\hline ROA & 179 & 5.40 & 4.81 & 3.63 & 0.46 & 17.29 & 2.81 & 6.94 \\
\hline ROE & 179 & 8.69 & 7.50 & 5.87 & 1.33 & 29.41 & 5.01 & 10.75 \\
\hline CSR & 179 & 63.09 & 62.98 & 2.58 & 55.24 & 69.92 & 61.49 & 65.03 \\
\hline $\mathrm{EC}$ & 179 & 3.47 & 3.43 & 0.30 & 2.47 & 5.00 & 3.27 & 3.67 \\
\hline Size & 179 & 26.54 & 26.44 & 1.16 & 24.39 & 29.74 & 25.88 & 27.08 \\
\hline Lev & 179 & 79.10 & 63.22 & 62.03 & 10.09 & 295.70 & 30.19 & 109.53 \\
\hline Ads & 179 & 0.794 & 0.083 & 1.670 & 0.000 & 9.499 & 0.023 & 0.579 \\
\hline
\end{tabular}

Table 4. Correlations.

\begin{tabular}{cccccccc}
\hline Variable & ROA & ROE & CSR & EC & Size & Lev & Ads \\
\hline ROA & 1 & $0.909^{* * *}$ & $0.301^{* * *}$ & $0.240^{* *}$ & 0.053 & $-0.290^{* * *}$ & 0.055 \\
ROE & & 1 & $0.256^{* * *}$ & $0.236^{* * *}$ & 0.034 & -0.007 & 0.035 \\
CSR & & & 1 & $0.216^{* * *}$ & 0.085 & -0.117 & 0.087 \\
EC & & & & 1 & $0.153^{* *}$ & -0.040 & $0.144^{*}$ \\
Size & & & & & 1 & 0.063 & 0.094 \\
Lev & & & & & & 1 & -0.008 \\
Ads & & & & & & & 1 \\
\hline
\end{tabular}

Note: ${ }^{* * *} p<0.01,{ }^{* *} p<0.05$, and ${ }^{*} p<0.10$.

Table 5 presents the results of the regression analyses using financial performance as the dependent variable, CSR as the independent variable, and employee commitment as the mediator, while controlling for size, leverage, advertising expense, industry, and year. First, the effect of CSR on ROA and ROE was tested; ROA and ROE were used as proxies of financial performance. Both ROA and ROE in model 1 were significant at the $p<0.01$ level, and financial performance was seen to be strongly and positively affected by $\mathrm{CSR}_{\mathrm{t}}$ for all models. These results strongly support $\mathrm{H} 1$ and are consistent with the results of previous studies, which found a positive relationship between CSR and financial performance.

Table 5. Regression results.

\begin{tabular}{cccccc}
\hline \multirow{2}{*}{ Variables } & \multicolumn{2}{c}{ Model 1 (H1) } & \multicolumn{2}{c}{ Model 2 } & Model 3 (H2) \\
\cline { 2 - 6 } & ROA $_{t+1}$ & ROE $_{t+1}$ & EC & ROA $_{t+1}$ & ROE $_{t+1}$ \\
\hline Intercept & $-17.704^{* *}$ & $-24.430^{* * *}$ & $1.505^{* *}$ & $-18.600^{* *}$ & $-29.442^{* *}$ \\
CSR & $0.356^{* * *}$ & $0.529^{* * *}$ & $0.018^{* *}$ & $0.318^{* * *}$ & $0.478^{* * *}$ \\
EC & & & & $1.622^{*}$ & $3.045^{* *}$ \\
Size & 0.123 & 0.055 & $0.026^{*}$ & 0.026 & $0.058^{* *}$ \\
Lev & $-0.016^{* * *}$ & -0.001 & 0.000 & $-0.016^{* * *}$ & -0.002 \\
Ads & 0.162 & 0.241 & $0.027^{*}$ & 0.122 & 0.163 \\
Industry & included & included & included & included & included \\
Year & included & included & included & included & included \\
N & 179 & 179 & 179 & 179 & 179 \\
$\mathrm{R}^{2}$ & 0.264 & 0.188 & 0.199 & 0.278 & 0.209 \\
Adjusted $\mathrm{R}^{2}$ & 0.201 & 0.119 & 0.130 & 0.212 & 0.136 \\
F-value & $4.195^{* * *}$ & $2.715^{* * *}$ & $2.904^{* * *}$ & $4.1944^{* * *}$ & $4.194^{* * *}$ \\
\hline
\end{tabular}

Note: ${ }^{* * *} p<0.01, * * p<0.05$, and ${ }^{*} p<0.10$.

Second, the effect of CSR on EC was examined. The coefficient of CSR is positive and significant $(p<0.05)$, which indicates that employee commitment is strengthened when CSR performance is increased. This result also indicates that the condition for the mediating effect is fulfilled. Finally, the 
coefficient of employee commitment in model 3 was significant when controlling for the effect of CSR. The results prove not only the direct effect of CSR on financial performance, but also the mediating effect of employee commitment on financial performance as measured by ROA and ROE, thereby lending support to $\mathrm{H} 2$.

Overall, the findings support the assertion that CSR directly contributes to an increase in profitability and indirectly to the achievement of a firm's financial performance by enhancing employee commitment. These results show that CSR can be a strategic resource for enhancing a firm's performance, as CSR contributes to employee commitment and ultimately profitability, rather than only being a cost.

\section{Discussion}

The demand for businesses to engage in socially responsible behavior has raised the question of the potential benefits of CSR initiatives for firms. This study highlights the role of employees as internal stakeholders while addressing the research framework that socially responsible behavior by a firm influences employees, which in turn affects the performance of a firm. The results suggest that CSR has an indirect impact on firm performance via employee commitment, as well as a direct impact. Firm performance in terms of macro outcomes can be attained through changes in employee attitudes as micro events [51]. This study stresses the role of employees because they have legitimate power and the ability to monitor and control CSR planning and implementation of the firm. In addition, the results are congruent with knowledge from the SHRM literature, in which it has been found that firm performance can be increased by changes in employee attitude and behavior (e.g., [41]). When employees are positively inspired by organizational systems, practices, or policies, they are more engaged in their jobs and with the organization.

The current study contributes in several ways to the body of CSR research and provides perspectives on issues that have not been previously addressed. First, this study adopted the stakeholder perspective by focusing on the role of employees to explain the effects of CSR on firm performance. Stakeholder theory addresses that firm should build a good relationship with all stakeholders because CSR can improve financial performance through indirect benefits such as stakeholders' dedication, know-how, sound culture, and corporate reputation [52]. Ethical practices and policies that employees perceive to be fair and transparent may increase employee commitment to the organization. Thus, the responsible behavior of members in an organization may influence others by reinforcing their positive attitudes. Conversely, if employees consider the organization to be irresponsible, they may punish the company [10]. The results of this study support that, despite the additional costs in CSR, companies benefit through an improved relationship with their stakeholders [53].

Second, the current study investigated both the direct and indirect impacts of CSR on firm performance. Some previous research has shown CSR has a direct impact on a firm's financial performance, while other studies (e.g., [30].) have detected only an indirect effect of CSR on financial performance through employee attitude and behavior. As a recent review of CSR study mentioned, the relationship between CSR and firm performance could be linked but the few studies has addressed the roles of mediators [54]. Thus, previous studies which investigated the effects of mediators could be distinguished with two streams such as internal resources and capabilities and external stakeholder [54]. That is, this study expands the roles of internal stakeholder as mediator which have not been clearly defined in CSR studies.

Third, the measures employed in this study were drawn from three different sources: the KEJI, $\mathrm{HCCP}$, and financial data. The use of multiple measures minimized the problem of common method bias and overcame the bias of company-sponsored questionnaires (e.g., [29,55]. This study has generated substantial findings through the multi-sourcing of data, while previous literature has tended to focus on the employee perception of CSR initiatives and corporate performance (e.g., [31,56]).

Finally, most CSR studies have been conducted in western countries (e.g., US, UK), while it has been rare in developing countries with some exceptions of China and Taiwan [3]. CSR practices, polices, and/or systems are context-bound. Therefore, CSR practices in western countries may cause different 
results on firms in Korea. The results of this paper show that CSR is an important strategy in Korean economy where have been characterized as weak corporate governance and family-oriented ownership.

In addition to these theoretical contributions, a practical implication can be drawn from our findings. There are still divergent and even competing perspectives on the role of CSR activities in terms of a firm's profitability among various stakeholders. For example, top management may have a negative standpoint on CSR due to the cost of investment in CSR, whereas other stakeholders, such as employees and the government, tend to hold a more positive perspective [57]. Such different approaches may cause inefficient strategic decision making, so firms have to develop systems that can cope with various needs. Therefore, employees are fundamental resources that firms can utilize to achieve business goals. A firm can ask for its employees to dedicate their efforts toward strategic goals by providing the opportunity for them to participate in CSR activities, rather than to simply observe them. When employees are given the rights and duties to participate in decision-making processes related to their firm's CSR systems and activities, they are more likely to exert effort in implementing CSR activities because they regard this as part of their formal duties.

\section{Limitations and Directions for Future Research}

This research has some limitations. First, although the companies included in this study were selected from three different data sources, many companies were eliminated due to a mismatch between the KEJI, HCCP, and KisValue data. In addition, our sample consisted of listed companies from the Korean stock market, which means that small and medium-sized companies were not included in this study. Future research needs to include small and medium-sized companies, as well as listed companies, to investigate the differences in the effects of CSR on firm performance for different businesses because the systems and practices of CSR depend on a firm's capabilities and resources.

Second, firm performance can be measured with several variables, such as Tobin's $Q$ and CAR (Cumulative Abnormal Returns) which is a measure of firm value based on market price and reflects publicly available information. Li, Minor, Wang, and Yu [58] explores stock market reactions to corporate social performance employing CAR. They demonstrated the interesting results that CSR reputation contributes positively to a firm's short-term superior performance, while abnormal returns decrease as the market gradually learns about the value of firms' social performance. Ref [59] focuses on the effect of CSR standing on CEO's future risk-taking financial incentives. They prove that firms with better CSR performance realize insurance-like benefits that can insulate managers from external discipline, which in turn mitigate the agency problem of "risk-shirking". Therefore, future research needs to investigate the impacts of CSR on firm performance with various outcome measures.

Additionally, it is possible that CSR influences a number of diverse employee attitudes and behaviors. Although this study adopted employee commitment as a major variable of employee attitude, future research could investigate the relationships between different variables, such as organizational justice, trust, and identification, as related to employee attitude and behavior. As examined in the study of Chun et al. [30], attitudes can precede behaviors and in turn, affect firm performance.

Finally, CSR activities targeting different stakeholders can have their own unique impacts on firm performance [60]. Although the KEJI index, which includes six individual categories, represents an integrated degree of CSR activities, each area may have a heterogeneous impact on stakeholders. Customers may possess more power, legitimacy, and urgency than employees because firms prioritize their relationships with customers. Among the six categories of the KEJI index, customers are more likely to focus on customer protection, while employees may require more investment in employee satisfaction. Firms have to allocate their limited resources to maximize their outcomes. From this perspective, future research needs to investigate the distinct impacts of CSR activities on different stakeholders. 
Author Contributions: Conceptualization, J.M.Y. and W.C.; data curation, M.L.C.; writing-original draft preparation, J.M.Y., W.C. and M.L.C.; writing—review and editing, J.M.Y., W.C. and M.L.C.

Funding: This research was supported by the National Research Foundation of Korea(NRF) grant funded by the Korea government (Ministry of Science and ICT), grant number No. 2017S1A5A2A03069098. The APC was funded by the Korea government (Ministry of Science and ICT).

Conflicts of Interest: The authors declare no conflict of interest.

\section{References}

1. Lougee, B.; Wallace, J. The corporate social responsibility (CSR) trend. J. Appl. Corp. Financ. 2008, 20, 96-108. [CrossRef]

2. Bhattacharya, C.B.; Sen, S. Doing better at doing good: When, why, and how consumers respond to corporate social initiatives. Calif. Manag. Rev. 2004, 47, 9-25. [CrossRef]

3. Alshehhi, A.; Nobanee, H.; Khare, N. The impact of sustainability practices on corporate financial performance: Literature trends and future research potential. Sustainability 2018, 10, 494. [CrossRef]

4. Burke, L.; Logsdon, J.M. How corporate social responsibility pays off. Long Range Plan. 1996, 29, 495-503. [CrossRef]

5. Aguinis, H.; Glavas, A. What we know and don't know about corporate social responsibility: A review and research agenda. J. Manag. 2012, 38, 932-968. [CrossRef]

6. Freeman, R.E. Strategic Management: A Stakeholder Approach; Pitman Publishing: Boston, MA, USA, 1984.

7. Schuler, D.A.; Cording, M. A corporate social performance-corporate financial performance behavioral model for consumers. Acad. Manag. Rev. 2006, 31, 540-558. [CrossRef]

8. Morgeson, F.P.; Aguinis, H.; Waldman, D.A.; Siegel, D.S. Extending corporate social responsibility research to the human resource management and organizational behavior domains: A look to the future. Pers. Psychol. 2013, 66, 805-824. [CrossRef]

9. O'Riordan, L.; Fairbrass, J. Managing CSR stakeholder engagement: A new conceptual framework. J. Bus. Ethics 2014, 125, 121-145. [CrossRef]

10. Gond, J.P.; Moon, J. Corporate Social Responsibility Volume 2; Routledge: New York, NY, USA, 2012; pp. $137-166$. ISBN 978-0-415-54806-9.

11. Carroll, A.B. A three-dimensional conceptual model of corporate performance. Acad. Manag. Rev. 1979, 4, 497-505. [CrossRef]

12. Carroll, A.B. The pyramid of corporate social responsibility: Toward the moral management of organizational stakeholders. Bus. Horiz. 1991, 34, 39-48. [CrossRef]

13. Schwartz, M.S.; Carroll, A.B. Corporate social responsibility: A three-domain approach. Bus. Ethics Q. 2003, 13, 503-530. [CrossRef]

14. Garriga, E.; Mele, D. Corporate social responsibility theories: Mapping the territory. J. Bus. Ethics 2004, 53, 51-71. [CrossRef]

15. Waddock, S.A.; Graves, S.B. The corporate social performance-financial performance link. Strateg. Manag. J. 1997, 8, 303-319. [CrossRef]

16. Luo, X.; Bhattacharya, C.B. Corporate social responsibility, customer satisfaction, and market value. J. Mark. 2006, 70, 1-18. [CrossRef]

17. Chon, M.L.; Yoo, J.M. Corporate social responsibility and financial performance-Investigating the moderating effects of motive and commitment of CSR. Korean Manag. Rev. 2013, 42, 1159-1186.

18. McWilliams, A.; Siegel, D.; Wright, P.M. Corporate social responsibility: Strategic implications. J. Manag. Stud. 2006, 43, 1-18. [CrossRef]

19. Margolis, J.D.; Walsh, J.P. Misery loves companies: Rethinking social initiatives by business. Adm. Sci. Q. 2003, 48, 268-305. [CrossRef]

20. Orlitzky, M.; Schmidt, F.L.; Rynes, S.L. Corporate social responsibility and financial performance: A meta-Analysis. Organ. Stud. 2003, 24, 403-441. [CrossRef]

21. McWilliams, A.; Siegel, D. Corporate social responsibility: A theory of the firm perspective. Acad. Manag. Rev. 2001, 26, 117-127. [CrossRef]

22. Barnett, M.L. Stakeholder influence capacity and the variability of financial returns to corporate social responsibility. Acad. Manag. Rev. 2007, 32, 794-816. [CrossRef] 
23. Cordeiro, J.J.; Tewari, M. Firm characteristics, industry context, and investor reactions to environmental CSR: A stakeholder theory approach. J. Bus. Ethics 2015, 130, 833-849. [CrossRef]

24. Jones, D.A. Does serving the community also serve the company? Using organizational identification and social exchange theories to understand employee responses to a volunteerism programme. J. Occup. Organ. Psychol. 2010, 83, 857-878. [CrossRef]

25. Freeman, R.E.; Reed, D.L. Stockholders and stakeholders: A new perspective on corporate governance. Calif. Manag. Rev. 1983, 25, 88-106. [CrossRef]

26. Aguilera, R.V.; Rupp, D.E.; Williams, C.A.; Ganapathi, J. Putting the S back in corporate social responsibility: A multilevel theory of social change in organizations. Acad. Manag. Rev. 2007, 32, 836-863. [CrossRef]

27. Rowley, T.; Berman, S. A brand new brand of corporate social performance. Bus. Soc. 2000, 39, $397-418$. [CrossRef]

28. Baker, T.L.; Hunter, T.G.; Andrews, M.C. Promoting ethical behavior and organizational citizenship behaviors: The influence of corporate ethical values. J. Bus. Res. 2006, 59, 849-857. [CrossRef]

29. Brammer, S.; Millington, A.; Rayton, B. The contribution of corporate social responsibility to organizational commitment. Int. J. Hum. Resour. Manag. 2007, 18, 1701-1719. [CrossRef]

30. Chun, J.S.; Shin, Y.; Choi, J.N.; Kim, M.S. How does corporate ethics contribute to firm financial performance? The mediating role of collective organizational commitment and organizational citizenship behavior. J. Manag. 2013, 39, 853-877.

31. De Roeck, K.; Maon, F. Building the theoretical puzzle of employees' reactions to corporate social responsibility: An integrative conceptual framework and research agenda. J. Bus. Ethics 2018, 149, 609-625. [CrossRef]

32. Peterson, D.K. The relationship between perceptions of corporate citizenship and organizational commitment. Bus. Soc. 2004, 43, 296-319. [CrossRef]

33. Turker, D. How corporate social responsibility influences organizational commitment. J. Bus. Ethics 2008, 89, 189-204. [CrossRef]

34. Porter, L.W.; Steers, R.M.; Mowday, R.T.; Bouilan, P.V. Organizational commitment, job satisfaction, and turnover among psychiatric technicians. J. Appl. Psychol. 1974, 59, 603-609. [CrossRef]

35. Tajfel, H. Social psychology of intergroup relations. Annu. Rev. Psychol. 1982, 33, 1-39. [CrossRef]

36. Tajfel, H.; Turner, J.C. The social identity theory of intergroup behavior. In Psychology of Intergroup Relations, 2nd ed.; Worchel, S., Austin, W.G., Eds.; Nelson-Hall: Chicago, IL, USA, 1985; pp. 7-24.

37. Ashforth, B.E.; Mael, F. Social identity theory and the organization. Acad. Manag. Rev. 1989, 14, $20-39$. [CrossRef]

38. Cullen, J.B.; Victor, B.; Bronson, J.W. The ethical climate questionnaire: An assessment of its development and validity. Psychol. Rep. 1993, 73, 667-674. [CrossRef]

39. Hess, D.; Rogvsky, N.; Dunfee, T.W. The next wave of corporate community involvement: Corporate social initiatives. Calif. Manag. Rev. 2002, 44, 110-125. [CrossRef]

40. Dyer, L.; Reeves, T. HR strategies and firm performance: What do we know and where do we need to go. Int. J. Hum. Resour. Manag. 1995, 6, 656-670. [CrossRef]

41. Becker, B.E.; Huselid, M.A.; Pinckus, P.S.; Spratt, M.F. HR as a source of shareholder value: Research and recommendations. Hum. Resour. Manag. J. 1997, 31, 39-47. [CrossRef]

42. Akpinar, A.; Jiang, Y.; Gomez-Mejia, L.R.; Berrone, P.; Walls, J.L. Strategic Use of CSR as a Signal for Good Management; IE Business School Reports Working Paper; 2008; Available online: https://papers.ssrn.com/ sol3/papers.cfm?abstract_id=1134505 (accessed on 5 November 2019). [CrossRef]

43. Dawkins, C.E.; Frass, J.W. An exploratory analysis of corporate social responsibility and disclosure. Bus. Soc. 2008, 52, 245-281. [CrossRef]

44. Barnea, A.; Rubin, A. Corporate social responsibility as a conflict between shareholders. J. Bus. Ethics 2010, 97, 71-86. [CrossRef]

45. McWilliams, A.; Siegel, D. Corporate social responsibility and financial performance: Correlation or misspecification? Strateg. Manag. J. 2000, 21, 603-609. [CrossRef]

46. Choi, H.J.; Moon, D.C. The relationship between corporate social responsibilities and accounting transparency. Korean Account. Rev. 2013, 38, 135-171.

47. Jang, J.I.; Choi, H.S. The relation between corporate social responsibility and financial performance. Daehan J. Bus. 2010, 23, 633-648. 
48. Meyer, J.P.; Allen, N.J. Testing the "side bet theory" of organizational commitment: Some methodological considerations. J. Appl. Psychol. 1984, 69, 372-378. [CrossRef]

49. Bliese, P.D. Within-group agreement, non-independence, and reliability: Implications for data aggregation and analysis. In Multilevel Theory, Research, and Methods in Organizations; Klein, K.J., Kozlowski, S.W.J., Eds.; Jossey-Bass: San Francisco, CA, USA, 2000; pp. 349-381.

50. Baron, R.M.; Kenny, D.A. The moderator-mediator variable distinction in social psychological research: Conceptual, strategic, and statistical considerations. J. Personal. Soc. Psychol. 1986, 51, 1173-1182. [CrossRef]

51. Scott, R.W. Institutions and Organizations; Sage: Thousand Oaks, CA, USA, 1995.

52. Wu, C.F. The study of the relations among ethical considerations, family management and organizational performance in corporate governance. J. Bus. Ethics 2006, 68, 165. [CrossRef]

53. Akben-Selcuk, E. Corporate social responsibility and financial performance: The moderating role of ownership concentration in Turkey. Sustainability 2019, 13, 3643. [CrossRef]

54. Grewatsch, S.; Kleindienst, I. When does it pay to be good? Moderators and mediators in the corporate sustainability-corporate financial performance relationship: A critical review. J. Bus. Ethics 2017, 145, 383-416. [CrossRef]

55. Maignan, I.; Ferrell, O.C. Antecedents and benefits of corporate citizenship: An investigation of French business. J. Bus. Res. 2001, 51, 37-51. [CrossRef]

56. Glavas, A.; Godwin, L.N. Is the perception of 'goodness' good enough? Exploring the relationship between perceived corporate social responsibility and employee organizational identification. J. Bus. Ethics 2013, 114, 15-27. [CrossRef]

57. Oh, W.Y.; Chang, Y.K.; Martynov, A. The effect of ownership structure on corporate social responsibility: Empirical evidence from Korea. J. Bus. Ethics 2011, 104, 283-297. [CrossRef]

58. Li, Z.F.; Minor, D.B.; Wang, J.; Yu, C. A learning curve of the market: Chasing alpha of socially responsible firms. J. Econ. Dyn. Control 2019, 109, 103772. [CrossRef]

59. Dunbar, C.; Li, F.; Shi, Y. Corporate social responsibility and CEO risk-taking incentives. J. Corp. Financ. 2019. [CrossRef]

60. Clarkson, M.B.E. A Stakeholder framework for analyzing and evaluating corporate social performance. Acad. Manag. Rev. 1996, 20, 92-117. [CrossRef]

(C) 2019 by the authors. Licensee MDPI, Basel, Switzerland. This article is an open access article distributed under the terms and conditions of the Creative Commons Attribution (CC BY) license (http://creativecommons.org/licenses/by/4.0/). 